\title{
Coated Tablet Dosage Form
}

National Cancer Institute

\section{Source}

National Cancer Institute. Coated Tablet Dosage Form. NCI Thesaurus. Code C42897.

A tablet whose outer shell is covered with a substance. 